Marquette University

e-Publications@Marquette

English Faculty Research and Publications

English Department

5-16-2017

\title{
Milton and the Logic of Annihilation
}

John E. Curran Jr.

Marquette University

Accepted version. Milton Quarterly, Vol. 51, No. 1 (May 16, 2017): 1-22. DOI. (C) 2017 John Wiley \& Sons, Inc. Used with permission. 


\section{Milton and the Logic of Annihilation}

Does Paradise Lost earnestly advance a "great argument," in the logical sense? Does the poetry construct a case for God's justice on rational, philosophical premises? While I construe this question as

far from decided, my purpose in this essay is to lend some support, however tentative and indirect, for an affirmative answer. This I will try to do by examining Milton's treatment of an issue on which he did express logical convictions, but on which he eventually fell into a logical trap because of the Bible. I suggest that if we detect him trying to gloss over this trap, what we are seeing is an urge to justify God's ways logically, but one which Milton is constrained to curb. The specific issue is that of annihilation; a focus there will point to a Milton who does care about logic, but who is prevented by the Bible from applying the full force of it. Logic leads Milton to an ex deo creation and to its corollary, a nonannihilable universe - but thence he is led toward another corollary, universal salvation. And of this the Bible deprives him, at least in his reading of it. Some passages, I hope to show, betray Milton feeling this deprivation, and feeling, coordinately, uneasy with the concept of an eternal hell, illogical as well as harsh. With Chaos and Moloch, in particular, we have prime instances of Milton's evasiveness with the problem posed by annihilation, an evasiveness that reveals, I think, his awareness of it as a problem and his wish, which the Bible makes unfulfillable, that he could posit universal salvation.

In addressing the very basic question of whether Paradise Lost renders a demonstration of Miltonic principles of theological philosophy, scholars have achieved much in the way of fine interpretations but little in the way of consensus. Even if we exempt the deconstructive readings tracing back ultimately to the Empsonian school, and set aside for our purposes here the idea of Milton's subversion of God, on the poet’s commitment to logical comprehensibility we shall not meet much agreement. The anti-logic side would seem to have more adherents, but among themselves they disagree, 
for example on whether Milton poeticizes what for him are foregone conclusions, ${ }^{1}$ or deliberately fosters uncertainty and irresolvable conundrums. ${ }^{2}$ Meanwhile, the positing of a logical Milton, while associated with older authorities like Denis Saurat and Maurice Kelley, persists in much more recent commentary as well, with Joad Raymond declaring that Milton “writes with a startling literalism” (199-200). ${ }^{3}$ Interestingly, however, readers who grant importance to Milton’s logicality, troubling themselves to refer to Milton’s own Art of Logic, can come close, accidentally or not, to turning back to an idea, like Stanley’s Fish’s, of Milton mostly subordinating discursive reasoning to what is self-evident—creating a universe of “tautological auto referentiality,” in John T. Connor's words (194). ${ }^{4}$ With this extra wrinkle, it seems like the question of Milton's true degree of logical purposefulness retains all its stubbornness.

While not presuming to resolve it, however, I propose that the case-study of the philosophical impossibility of annihilation, and what I will term its missing consequent, universal salvation, can speak somewhat to the affirmative side, by providing an exception to the rule; Milton's overall attentiveness to logical exposition and coherency might be observable in how he handles fissures in the design. My discussion is in part inspired by an older study both well-known and overlooked, Dennis Burden’s seminal Logical Epic. Professor Fowler having extensively drawn on it for his magisterial edition, many

\footnotetext{
${ }^{1}$ See Fish's case that "affirming God is not something you do on the basis of evidence" (10); this argument resonates, with some variety, in, for example, Thomas Greene, The Descent from Heaven: A Study in Epic Continuity (New Haven: Yale UP, 1963) 363-411; Teskey 4-5, 100-01; James Dougal Fleming, Milton's Secrecy and Philosophical Hermeneutics (Aldershot: Ashgate, 2008) 7-9.

${ }^{2}$ See Herman, quite influential on this view, on how by the time of Paradise Lost Milton had been shaken out of his former confidence that "the intellectual and moral rightness of God's will" could be squared with "the exercise of human reason" (114-15). On this basic point of Milton's philosophical ambiguity see also for example Sewell 79-84; Haskin xvii, 183-84; Lieb 5-6, 163-83; Mascetti 36; Sugimura xvi, 216-30.

${ }^{3}$ For Saurat "[t]here was nothing of the mystic about Milton" (68), and this precise rationality led him to hold that, whatever its feebleness, human understanding in contemplating God could always fall back on the "principle of non-contradiction" (95-96). Kelley validated the correspondences he found between Milton's epic and his systematic theology by affirming Milton a man of his time, and, despite our modern misgivings, "what men of the seventeenth century said in their writings is indicative of what they believed" (216). On Milton's commitment to rationality see also Curry 10-11, 182; Robins 59; Jacobus 188; Fallon 15-16, 165, 183; Marjara 44-59; Reisner 17183; Catherine Gimelli Martin, Milton Among the Puritans: The Case for Historical Revisionism (Farnham: Ashgate, 2010) 24-26; Danielson 3-4.

${ }^{4}$ See also Howard 151-54, vs 167, 170-72; Thomas S. K. Scott-Craig, "The Craftsmanship and Theological Significance of Milton's Art of Logic," Huntington Library Quarterly 17 (1953): 1-16; Fisher 46; Arnold x-xii, 23-24; Donnelly 38-48.
} 
Milton students are familiar with Burden’s book, but it is not, in my experience, very often cited in considering the poet’s philosophical rigor. For Burden, Milton felt that "any snags or difficulties that the Bible narrative provided had to be smoothed out into reason and system” (4). "He had an almost obsessive determination to see the world in rational terms" (5); thus, since his "poem is based necessarily on the Genesis account," it follows that "the way in which it handles the awkward problems that arise when that account has to be seen as compatible with the idea of a provident God is an organic part of its nature” (6). Milton sets himself doggedly against such problems, and yet at times he cannot seem able outright to engage them. At some moments, such as those which threaten to prod us into wondering why God did not leave more opportunity for the fallen angels to repent, Milton resorts to what Burden calls "sleight of hand”; Abdiel for example is a Miltonic addition geared to insinuate his peers’ free decisionmaking in siding with Satan. At some points, Milton must be inventive and surreptitious in order to navigate the "(contradictory) logic of the theme” (38). Burden’s approach, that Milton applies himself to a logical demonstration of God's justice but at times must skirt intractable incongruities, seems to me to warrant further development, and might fruitfully be developed with closer attention to principles of logic and theological philosophy. Perhaps by looking at key "sleights of hand,” we can get a sense of the larger structure of Milton's great argument and of the sophistication and integrity with which he seems to have tried to put that structure in place.

On the specific question of annihilation, we shall see, if we draw from Christian Doctrine and Art of Logic in conjunction with Paradise Lost, that Milton's response ties the strands together in a way that eventually necessitates sleight of hand—he argues himself into a logical corner, and needs temporarily to abandon logic and adopt diversionary tactics in order to get past it. In building his theological philosophy on the premise that the Bible, insofar as the text was reliable, was essentially incontrovertible, Milton left himself an opening for relaxation with regard to logic. Wherever the Scripture was mystifying, mystery could simply be posited. But Milton seldom took this opening. Instead, his Christian Doctrine generally holds that a given point of doctrine can be elucidated, and correctly, if only the relevant Bible passages 
speaking to it might be gathered and syncretized, and the distorting force of tradition and custom nullified. In fact, often for Milton, contrary to a predominant strain in Protestant thought, the primary force of this distortion lay not in its displacement of faith by philosophy, but in its insufficiently logical philosophizing. A properly logical analysis can unravel many doctrinal issues that seem thorny only because of human intellectual inertia; and Milton makes plain that he feels qualified to conduct such analysis, in that his God though infinite is still subject to basic logical rules. Heterodox though his conclusions tend to be, he casts them as virtually inevitable from any valid reasoning making its inferences from the Scripture-and assuming a logically coherent deity. Among these conclusions is his position on the matter of creation, that it derived out of God rather than the orthodox out-of-nothing. For Milton creatio ex deo was inescapable from many premises; it certainly complemented his much discussed philosophical monism, but more than this, it followed clearly from logical principles, in particular those of contrariety and causality. And from this conclusion certain others were locked into place, including that God cannot annihilate anything. But then, what are we to think of the eternal punishment to be visited upon fallen angels and reprobate humans? The universal salvation that would logically follow from Milton's reasoning up to this juncture is made unavailable to him by the Bible. And so here, at moments in his poem where this impasse would seem to rear its head, he is induced poetically to deflect attention from it and employ sleight of hand—-two such deflections being Chaos and Moloch.

First we must ask, was Milton at all attracted to universal salvation? While on the surface it cannot appear so, some notes of attraction may be found if we read between the lines. In observing the sparsity and reserve with which he comments on the world's final conflagration, in Christian Doctrine $1.33,{ }^{5}$ scholars have themselves been reluctant to ascribe his reluctance to any latent inclination toward saving even the devils. Though others have pointed out the awkwardness of the passage, Robert M. Myers

\footnotetext{
${ }^{5}$ All references to the prose are from the Columbia edition, and are to book and chapter, and then to volume and page. For my translations, I have used this edition but have also consulted those in the Yale Complete Prose Works $(C P W)$.
} 
has few corroborators in tying it to a discomfort on Milton's part with the doctrine of an eternal hell (4547). ${ }^{6}$ But perhaps discomfort is discernible. The passage begins with an admonishment against our asking beyond what "scire nobis expedit" [it benefits us to know]; Scripture tells us as much about the conflagration as is good for us, even though it withholds an answer to the question it provokes Milton to provoke us with: "utrum ad substantiae abolitionem an ad qualitatum duntaxat immutationem” [whether to the wiping out of substance or to the alteration of qualities] (16:368). Since Milton has already established the prospect of an abolition of matter as an impossibility, more about which in a moment, and since his principal sources, Ames and Wolleb, were unbothered by the issue, ${ }^{7}$ Milton’s asking the question, leaving it open, and then declaring it not-to-be-questioned has the effect of hinting that speculation on what ultimately becomes of fallen sentient beings is natural but dangerous. It is difficult not to wonder as to the properties of substances eternally tormented, but Milton even as he broaches the topic cuts himself, and us, off from such wondering. The mere fact of eternal and irrevocable hellsuffering must be taken as such, as mere fact, but for us to take it so, it seems, it must be abstracted from the conditions thereof. And in the course of prompting us to this abstracting, the abstracting of the fact from its conditions, Milton has referenced one of the only notions that could relieve the tension, the notion of annihilation-- substantiae abolitionem--even though he had earlier confirmed it impossible. What this suggests is an urge for such relief, an impulse to maintain the possibility of conceptualizing eschatological punishment as something other than unending and un-endable torture.

\footnotetext{
${ }^{6}$ For Brodwin, aligning Milton with Socinianism, any implicit pity for the devils points to dissolving rather than saving them. In Juliet Cummins's collection on Miltonic eschatology, Milton and the Ends of Time, only Shawcross's essay refers to the issue, and this only to show Milton's caution given biblical "uncertainties" ("Confusion" 114). Cummins herself posits a continuation for the post-conflagration damned of the dissolution they experienced before, "brought on by sin itself " (180). For readers like Trevor and McColley, Milton's anxiety about the final conflagration is about what union with God entails for the self, not what eternal hell means for God's justice. ${ }^{7}$ Ames decides easily, and merely says that "The elements shall not be taken away, but changed" (189). Wolleb after a confusing synopsis of the controversy slants to the same view, but apparently deems either to be acceptable, and the question to be a thing indifferent with regard to salvation (198-200). See notes CPW 6:627-30. On these sources see Introduction, CPW 6:17-20.
} 
This suggestion of an urge to keep open avenues he knows are indeed closed is all the more striking when Milton soon makes it again. Is hell located in or on the same plane as earth? It does not seem likely that hell would be enfolded in earth's conflagration: with the whole world burning up, as the New Testament makes plain, “quid fiet inferno, si in terrae meditullio est situs? certe conflagret una necesse erit, et eandem cum terra sortem subeat. Quod si fieret, praeclare sane cum damnatis actum esset” [what would become of hell, if situated in the middle of earth? clearly it will be necessary that it burn up and share the same fate with earth. Which if it would happen, would obviously be healthfully done, for the damned] (16:374). Again, the inability of the damned to be annihilated is alluded to, even while Milton induces us to think about annihilation as a relatively humane alternative to eternal anguish. And here, to this referencing of unavailable alternatives is added an enhanced sense of immitigable harshness, as the damned would presumably prefer annihilation to an eternal hell. Thus in 1.33 we are twice pushed toward and then away from inquiry into the nature of an eternal hell, and led to consider alternatives to it, like annihilation, that we're made aware we cannot consider. Wolleb is untroubled at the logic of the conflagration, crisply assigning God as its efficient cause (“Causa efficiens consummationis huius erit Deus: eiusdem enim est mundum creare \& eundem destruere” (197)). Contrastingly, as John T. Shawcross put it, “Milton’s curious statement indicates that he did realize the inconsistencies and illogicality of Revelation” (“Stasis” 13-14).

But the biblical illogic of an eternal hell of course extends well beyond Revelation, and certainly encompasses Matthew 25.41, and here too Milton does not quite embrace the illogic plainly. This is a verse Milton thrice cites in 1.33 (16: 364, 370, 372): “Then shall he say vnto them on the left hand, Depart from me ye cursed, into euerlasting fire, which is prepared for the deuill and his angels.” Or, rather than illogic, we would more correctly say that the verse makes the eschatological scenario all too clear, as inescapable as the hell it posits. On this Ames is able to be blunt: the resurrection and judgment of the reprobate dead "doth no more argue the universall redemption of such men, then of the Devills” (189). But Milton while never contesting the spirit of the verse does not set down the letter in quite so stark 
terms as Ames’s. In Christian Doctrine 1.9, Matthew 25.41 is a verse proving “Angeli mali ad poenam reservati sunt” [the evil angels are reserved for punishment] (15:106); a large part of their misery is realization of this reserved-ness, “ut de salute sua plane desperent” [so that they completely despair about their salvation] (15:110). As clinched by its position in the same chapter as the parable of the talents, ${ }^{8}$ Matthew 25.41 cannot be ignored, and Milton does not ignore it; but he does not extrapolate much from it, either. The devils and the reprobate are to be kept in hell forever. But what beyond their despair the devils' torment actually consists of is not belabored, and neither is the possibility of their eventual release refuted. Universal salvation will not be taken up at all, not even, as in Ames, to be dismissed. Meanwhile, Milton slips into 1.33 a paragraph implying the uncertainty surrounding hell, given that "Poenarum gravitas et duratio varie describitur” [the severity of punishments and their length is variously described] (16:370). Is the protraction of hell-torment uncertain? We must be moving on to the next point, that the severity of pain is commensurate with the sin. The sense is that of Milton, in a manner distinguishing him from Ames and Wolleb, glancing toward a conversation that is already foreclosed upon—as though he would like to open such a conversation but cannot.

If some part of Milton did yearn for universal salvation, it would have been all the more seductive to him, given that other influences would have taught him that it was a viable way to imagine the conflagration, and maybe even a logically imperative one. Early Christian writers Gregory of Nyssa and Origen, both often discussed as making an impression on Milton, ${ }^{9}$ espoused universal salvation even though neither had a view of creation constraining him into it—each had the benefit of an ex nihilo

\footnotetext{
${ }^{8}$ For the centrality of the parable to Milton see the exhaustive argument of Haskin, esp 29-53, 91-117.

9 For Milton's rejection of universal salvation, associated with Origen and Gregory, see Patrides 281-82. For Origen and Milton the most extensive source remains Robins, see esp 31; but see also Curry 161-64; Saurat 222-25; Hart 16-19; Lieb 150; Trevor 86-92. For Gregory see for example Hunter 74-76; Sugimura 47; Reisner 44-47. Though he tries to read Gregory as favoring ex deo, a seminal source on the background of Milton's creation is Adamson 75760. For both Fathers and apocatastasis, see J. N. D. Kelly, Early Christian Doctrines $2^{\text {nd }}$ ed. (New York: Harper \& Brothers, 1960) 473-74, 483-86. For both Gregory and Origen I cite traditional partitioning when possible, and then page numbers from the editions used.
} 
universe. For each, universal salvation followed logically, especially on the basis of a different Bible passage, Paul's famous formulation for the end-times: “And when all things shall bee subdued vnto him, then shall the Sonne also himselfe be subiect vnto him, that did subdue all things vnder him, that God may be all in all” (1 Cor. 15.28).

In The Making of Man, Gregory validates philosophical speculation coordinating Scripture and reason (Letter to Peter, 387), and indicates that the limits of such coordination are fairly easy to see; while it follows from reason that creation should have an end if it had a beginning, it is beyond reason how God created matter out of nothing: "Consequently, as we suppose the power of the Divine will to be a sufficient cause to the things that are, for their coming into existence out of nothing, so too we shall not repose our belief on anything beyond probability in referring the World-Reformation to the same power" (23.5, 414). Ex nihilo would seem to be not so much an explanation of the how as a way to name what could not be explained after one had eliminated the unacceptable alternative explanations. Such is strongly implied when Gregory in On the Soul and the Resurrection elaborates on the incomprehensibility of creation's how, given that matter could not be coeternal with God, and so God must be the Cause, “and yet the existences produced by that Cause are not of the same nature as its transcendent quality” (457-58). With regard to creation, then, Gregory hits upon mystery not to emphasize an unfathomable God but to reaffirm what is fathomable about him; logic goes far, though it eventually must yield to mystery. And yet, with regard to the extensiveness of salvation, mystery is unneeded. An ex nihilo creation opens many opportunities to excuse evident vagaries in the biblical divine justice, but Gregory does not take them. Instead, in the same treatise he reasons that Paul's "all in all” passage must mean the annihilation of evil: "this utterance seems to me plainly to confirm the opinion we have already arrived at, for it means that God will be instead of all other things, and in all. ... and herein it appears to me that Scripture teaches the complete annihilation of evil” (452). If the term "in all” is to be "kept intact," all evil in the universe will have to have been drained away. 
For Origen, too, universal salvation would seem to be conclusive from the "all,” even despite his leaving himself possible logical or extra-logical exit-doors. He too adopted an ex nihilo creation, or at least so it appears in the De Principiis (2.1.4-5, 269-70), ${ }^{10}$ but his bent for allegorization could also furnish him with escape routes. In De Principiis 1.6 (260-62), Origen opens on the consummation of the world with a disclaimer that comment on such a topic must be provisional, and then points toward a spiritual significance for the "all in all” passage, applying the concept of subjection in it to the wholehearted dedication to Christ. But the chapter soon swerves from an allegorical approach to consummation: the heavens and the earth cannot be annihilated or destroyed, but must be changed; and such change entails the slow but unstoppable progress of rational creatures toward "that goal of happiness to which ... even enemies themselves are to be subjected, and in which God is said to be 'all and in all.” Nor does Origen back away from this stance, for later, in 3.6 (344-47), he affirms that an end to the world necessarily precludes the existence of any evil: “all in all” means the eventual removal of evil from the mind of each individual rational being, “and thus God will be ‘all,' for there will no longer be any distinction of good and evil, seeing evil nowhere exists.” God’s creative power cannot coincide with any destructive power, since "those things which were for existence cannot cease to be"; "and thus, through the numerous and uncounted orders of progressive beings who are being reconciled to God from a state of enmity, the last enemy is finally reached, who is called death, so that he also may be destroyed, and no longer be an enemy.” Such an attitude, moreover, is not unique to the De Principiis, but is conveyed in the Contra Celsum as well. Refuting his pagan interlocutor's insistence on the impossibility of ever resolving the diversity of rational creatures, Origen declares his conviction that "the Word shall prevail over the entire rational creation, and change every soul into His own perfection” $(8.72,667)$. Even while admonishing Celsus against a literalist reading of the conflagration, as though God were like a cook roasting the world, Origen makes clear that figurative interpretation, here of the burning of sinners, must still follow from the assumption of God's real benignity; by the punishing fires, God's purposes must be

\footnotetext{
${ }^{10}$ The passage is periphrastic and obscure, in the translation and in Rufinus' Latin; for the latter I've consulted the online Patrologia Graeca 11:185-86.
} 
understood not as punitive, but as purgative and rehabilitative (5.15-16, 549-50). Accordingly, God must never be understood, as Celsus thinks Christians understand him, to create rational beings only to abuse them, as though he "finds fault ... with his own handwork, and hates, and threatens, and destroys his own offspring” (6.53, 597-98).

Whether in laying out First Principles or in controverting pagans, Origen, like Gregory, turned to universal salvation to preserve God's goodness, even though ex nihilo creation might alleviate matters by partitioning God's imperfect productions off from the perfection of the producer himself. The contrast is instructive between these Fathers and Milton, who could not bring himself to use either method of justifying God, ex nihilo or universal salvation. As the most enthusiastic promoter of a connection between Milton and Origen, Harry Robins, observed, though Paradise Lost mentions the theoretical possibility of the devils’ repentance, and thus shows some interest in the prospect of it (137-38), “Milton nowhere attempts to explain how God can be 'all in all' when Satan, evil angels, and damned men are outside the realm of the blessed” (54). Indeed, Milton not only withholds an explanation, but also increases the logical exigency for one.

The "all in all” passage sits not well with a never-to-be-reclaimed hell, and the tension was all the greater the more God and creation were imagined as somehow continuous, with hell as an intrinsic part thereof. The "all in all” seems to portend a conflagration that is a final, total unifying, but envisioning this grows especially difficult with an eternal hell, conceived as neither coming from nothing nor reducible to it, subsisting alongside a universe conceived as constituted of, not merely by, God. We have a logjam here not susceptible to logical resolution—so it must somehow be evaded.

It is a logjam similar to that which Milton’s contemporary Henry More seems to have perceived, and his evasiveness toward it, even while he purports to face up to it, can help us read Milton’s. Even while ostensibly confronting dispassionately the final fate of fallen souls, More talks around the heart of 
the matter. In Immortality of the Soul (3.18.7-15, 227-30), ${ }^{11}$ More took it upon himself to review five different schools of thought on "the condition of the Soul after the Conflagration of the Earth,” and discounted annihilation, determining the soul's destruction by fire or by any created thing to be “impossible,” and by God to be incongruous, in that he would be creating an immortal being only to “uncreate it again.” Putting the souls eternally to sleep, their immortality pointless, did not make sense, and neither did dividing the soul's spirit from the burnt-up matter; but then, what about waking up the one-day reformed souls to a new and perfected world, an "Expergefaction into life”? This Stoic-derived notion is untenable, says More, in that it enforces a contradiction of creaturely identity: the renewed creature would not be anything of its former self and so would, effectively, live in perpetual death. Hence More decides to be undecided on the issue—it's "desperately undemonstrable”—conjecturing only that God must have some mechanism for rescuing still-alive-on-earth innocents from involvement in the conflagration's agonies. In a posture of philosophical caution in the pursuit of truth, More factors in the assumption of divine mercy, and yet simultaneously factors out the inferences about divine cruelty his analysis points to. The pattern recurs in A Platonick Song of the Soul: if we assume an eternal hell, the conflagration forces us to wonder "Why will not God save / All mankind?”; "Why be not damned souls devoyd of sense, / If nothing can from wickednesse reclaime, / Rather then fry in pain and vehemence / Of searching agony?” For those who never even had a chance to hear the Gospel, “for ever they must dwell / With cursed fiends, and burn in brimstone lake"; it seems that "ill infinitely more then good doth grow," and that "God would show much more benignity” if he should "Call back the creature to its ancient nullity” (Psychathanasia 3.4.28-32, 395-96). More derides the ignorance of such queries, but

\footnotetext{
${ }^{11}$ See Jasper Reid, The Metaphysics of Henry More (Dordrecht: Springer, 2012) 376-81.For Milton and More, see for example Jacobus 17-18; Schwartz 347-48; Fallon 50-78; Marjara 98; Sarah Hutton, "Mede, Milton, and More: Christ's College Millenarians," Milton and the Ends of Time, ed. Juliet Cummins (Cambridge: Cambridge UP, 2003) 29-41. I cite the traditional partitioning, and then pages from the editions used.
} 
instead of answering them, he proves why the world was not created from infinity — the dodge is presented as philosophical forthrightness. ${ }^{12}$

Twice in Paradise Lost, in passages explicitly alluding to the "all in all," there is a similar sense of pretended straightforwardness; in each place the idea of God's dissolution of everything goes along with that of an eternal hell, as though there were no awkwardness in the juxtaposition-even while we're made aware that there is. The God of Book Three looks forward to when "The world shall burn," and the Son shall put aside his governing power, "For regal sceptre then no more shall need, / God shall be all in all”; this triumph of love for "the just” coincides, "Meanwhile,” with how "hell, her numbers full, / Thenceforth shall be for ever shut” (3.330-41). It appears that the "all in all” and the eternal hell are simply the two diametric parts of the "dread tribunal” (326)_ justice will be meted out, and that will be that. And yet, we might still feel inclined to ask how the all could be in all and also be so ruthlessly exclusive, if we notice the way this particular juncture is hemmed in with features carrying a sense of a much less stark dispensation: the doors of hell being forever "shut" might well recall for us God's recent assurance that, toward repentant sinners, his eye would not be "shut" (193); we also might recall how the Son elicited this assurance when he admonished the Father as to the unseemliness of leaving a "whole race” to hell, which were to “Abolish” and incongruously "unmake” what he made for his glory (160-64); and the scene in heaven is occasioned by, and soon followed by, the progress of Satan's breaking loose from hell, with its sense that God punishes evil, and brings forth good from it, not by constriction, but by boundless space, with creatures running with their own motivations. ${ }^{13}$

The second such instance (6.730-35), again referring to the imperious, hard-judging divine "Sceptre," comes as the Son, departing from the divine "mildness" he customarily puts on, prepares to put

\footnotetext{
${ }^{12}$ Even on the issue of infinitude the passage is dodgy; see the editor Jacob's Analysis 72-73. More also asserts that union with God at the conflagration - "the finall consummation / Of all things" which makes the "Creature Deiform" - doesn't negate creaturely individuality, and here too the incongruity of the assertion is cast as resolved when it has not been; see Antimonopsychia 24-28 (Platonick Song 534-35), and Jacob's Analysis 117-18. ${ }^{13}$ For a discussion see Jules David Law, "Eruption and Containment: The Satanic Predicament in Paradise Lost," Milton Studies 16 (1982): 35-60.
} 
on the "terrors" of God and evict the rebel angels from heaven; the Son looks ahead to resigning the scepter, "when in the end / Thou shalt be all in all, and I in thee / For ever.” Again we must simply accept divine discrimination: all in all includes “all whom thou lov’st: / But whom thou hat'st, I hate.” And yet the Son's irresistible sweeping away of the soon-to-be-devils is, we are soon told, restrained: “for he meant / Not to destroy, but root them out of heaven” (854-55). In a way, this reconfirms an adamantine God, in that the destruction the Son refuses to grant the devils could well be, relatively, a boon to them; indeed, an eternal hell is, as the Son in Book Three terms it, the equivalent of unmaking. But in another way, the passage sounds a note of comparative softness, as though the idea of destruction, of unmaking, is disturbing enough to warrant dismissal. Even when conquering the rebel angels, even when putting on God's most terrible terrors, the Son “meant” an intention leavened with “mildness.”

The two "all in all” passages thus confront with a façade of candor the problem an eternal hell has for God's justice, but do so in ways hinting that the problem is there; it is a problem for which misdirection becomes keenly necessary once the ramifications of an ex deo creation stand are brought to bear. If we had no cosmological frame of reference for thinking about “all in all," we might ignore the problem and have recourse to sheer mystery—but we do have one, lent us from Raphael's lecture to Adam in Book Five: “one almighty is, from whom / All things proceed, and up to him return, / If not depraved from good, created all / Such to perfection, one first matter all” (469-72). On the poet’s materialist monism, as evidently articulated here, there is strong uniformity of scholarly opinion, ${ }^{14}$ though D. Bentley Hart ably critiques our certainty as to whether for Milton "creation is ontologically continuous with the divine” (16). But whatever the extent to which Raphael allows us to posit a strictly or technically materialist-monist Milton, the lecture does corroborate an ex deo cosmology and its entailed continuity between creator and creature. “All in all” in this light seems indeed to bind God to all his creations. How

\footnotetext{
${ }^{14}$ For confidence on Milton's monism, including analyses of Raphael's speech, see Hunter; Saurat 93-94, 112-18; Curry 158-82; Jacobus 44, 91-97; Schwartz 337-38; Fallon 1-16, 102-06; Cummins 169; Donnelly 49-69, 92-93; Raymond 279-80. For allowance for some ambiguity see for example Marjara 68-75, 220-25; Sugimura 41-57.
} 
this can account for some parts of creation never being "Improved by tract of time” (498) might seem to hang inconveniently in the air, only to get left there.

And yet, at this point we do well to notice that this lacuna is by no means a Miltonic norm; the ex deo proposition per se, aside from how an eternal hell was to be included, comes across as not problematic at all, but entirely logical. In fact, Raphael offers this cosmological framework explicitly to Adam's rationality. It is illustrative of his capacity to worship God using logic, as well as the logical nature of God's ways. For Raphael and for Christian Doctrine, the logic of ex deo, and its nonannihilation corollary, epitomizes how God's ways are amenable to human powers of reasoning.

From Raphael, we learn that all substance, however we understand its essential nature or materiality, finally derives from and finally returns back to God. Though at the risk of reinscribing the tension of how any segment of such God-derived substance could sustain its depravity unto infinity, that all is God-derived substance is driven home. At the same time, Raphael in the same lecture affirms that logical reasoning is the lens through which even pre-fallen humans are to apprehend, appreciate, and abide by God's order. Right Reason, ${ }^{15}$ the mechanism by which the unfallen created mind is induced to love and obedience, runs mostly on intuition in angels, but mostly on "Discursive” reasoning in humans; crucially, Raphael stipulates that intuition and discourse are different only in degree, being "of kind the same” (486-90). God's order makes sense to the angels largely because they feel it to make sense; it makes sense to Adam and Eve largely because they conclude so from a process of identifying premises and lining them up with one another. And Raphael says that this discursive way to God is of the same kind as the intuitive-it reliably leads to the same mental capacity, proportionally speaking, of remaining unfallen. Whether or not we take it as advocating precisely a recognizable monist philosophy, then, the lecture sets down terms in agreement with an ex deo creation, casts understanding the terms of God's

\footnotetext{
${ }^{15}$ Here I disagree with Arnold 41-57, where he reads Raphael as absolutely subordinating the discursive to the intuitive, which is equated with Right Reason.
} 
creation as reinforcing a proper love of him, and moreover makes clear that these terms are validly arrived at via human logical procedures.

Consonantly with Raphael, the endorsement of ex deo creation in Christian Doctrine goes along with the sanctioning of human discursive logic. ${ }^{16}$ On creation, as throughout the treatise, human reasoning is justly prevailed upon as long as it does not indulge overly voracious curiosity or overly free imagination — which is much in line with Raphael's position. Unusual in Christine Doctrine is Milton's backing off from theorizing on the how of two natures uniting in the incarnated Son: "Modus ignoratur et ignorari certe praestat quod Deus ignotum vult” [the manner is unknown, and certainly it is appropriate that that be unknown which God wants unknown]; “quo autem modo quoniam Deus id non ostendit, desinere argutari, et sapienter potius nescire” [since God has not shown by what means, stop disputing, and instead be wisely unknowing] (1.14, 15:270-72). Milton here, much as Raphael will do (8.173), enjoins a "lowly wise” approach to speculation, and yet even here logic is soon reasserted, as the mysterious union of natures jibes with what was earlier determined, logically, about the Father and Son having distinct essences; otherwise the Father would have to have joined the Son in union with the human nature, “quod impossibile est” [which is impossible]. Similarly, in my view, Raphael’s warning against excessive speculation actually goes along with encouragement that ideas can be entertained "not surpassing human measure” (7.640). Though God’s secrets are secret, human measure includes a “reasoning” (8.85) sufficient not only to think but to rethink its way through puzzles such as the relative significance of humans and the heavens: Adam can realign his assumption of what superiority is predicated on, so that he correctly "infers" bigness and brightness as not necessarily denoting it (8.90-91). Encapsulating what is, to me, a similarity between the poem and the treatise, in Raphael's lessons,

\footnotetext{
${ }^{16}$ This it must be noted is a controversial point. For studies arguing the dissonance between the poem and the treatise, esp regarding logic and creation, see for example Howard 167-68; Sewell x-xii, 1-34, 124-34; Rumrich, "Matter of Chaos" 1037-38; Sugimura 259-68. For Christian Doctrine itself as displacing logic with interpretive openness, see Jason A. Kerr, "Milton and the Anonymous Authority of De Doctrina Christiana," Milton Quarterly 49 (2015): 23-43. For an in-depth case for Raphael's being confused and confusing on human reason and learning, see Christopher Crosbie, "Publicizing the Science of God: Milton's Raphael and the Boundaries of Knowledge," Renascence 67 (2015): 239-60.
} 
whereas some knowledge is forbidden and some lines of inquiry shouldn't be pursued, logic is proposed as entirely good. In fact, logic can help show humans the boundaries of safe exploration. Raphael has discussed "motion in the heavens," but done so "to show / Invalid that which thee to doubt it moved" (115-16). Adam's inferring himself a paltry being stuck in an absurdly out-of-proportioned universe were invalid; through valid reasoning, he can conclude himself an awesome specimen of an awesome universe, however much of the particular workings of that universe he does or does not, or can or cannot, know.

Without contradicting the poem, where the treatise goes a step further is in allowing logic to show the boundaries restricting God himself (see Jacobus 181-88); Paradise Lost justifies the ways of God to men, and Christian Doctrine is explicit that those ways are just by our standards. Repeatedly Christian Doctrine's rule is reasoning, and not only reasoning, but reasoning the underlying principles of which govern God as much as they do us. The traditional concept of the Trinity, to resume this notorious example, is caught in hopeless tautology, relying on rational because lacking in scriptural support—and the rational support is bare self-ratifying statement, being in itself irrational (1.5, 14:216). But what made it irrational? Largely, it was irrational because divine arithmetic is the same as human, and “one” and "two" mean the same for God as for us. This we can tell from Scripture, because otherwise the First Commandment were nonsense; but then, what Scripture told is that God's math works like ours—-“ratio saltem unius et duorum apud Deum atque homines eadem semper sit” [the concept of one thing and two things is always the same with God and with men] $(1.5,14: 194$; see also 1.2, 14:50). Moreover, these fundamental principles applying to God and to humans alike are moral and judicial as well as mathematical and philosophical. Arminian doctrines of conditional election and sufficient grace follow necessarily from any basic idea of justice. Though Schoolmen have tried to wiggle out of it with quaint redefinitions and over-subtle distinctions, necessity means necessity, since there can be no other "nisi quam Logica, id est, ratio docet” [unless what Logic, that is, reason, teaches] (1.3, 14:70); and necessity necessarily abolishes creaturely free will $(1.3,14: 72)$. Than a necessity that does not necessitate, nothing could be more absurd $(1.4,14: 108)$. But why can't human actions be necessitated? We cannot content 
ourselves, as theologians have done before, with the self-contradiction of a fall that is both our fault and inevitable; and with this escape route disallowed, we, including our first parents, cannot have been coerced into any action, because in that case "profecto iam non ad gratiam, sed ad iustitiam Dei pertinuit necessario lapsu lapsum restituere” [then truly, to restore the fall, with the fall necessary, pertained not to the grace but to the justice of God] $(1.4,14: 100)$. If we can't help but sin, restoring us were required of God, or he'd not be treating us fairly. Milton's God counts with our numbers, and also counts himself just using our idea of justice.

Turning to creation in chapter 1.7, then, we again have the unorthodox proposition emerging against a failure of traditional ideas to employ adequate logic — and to subject God to it: "Nam neque virtus et efficientia divina potuisset iuxta communem sententiam corpora ex nihilo producere” [For the divine power and efficacy would not have been able to produce bodies out of nothing, as per the common opinion] (15:24). Milton jokes that ex nihilo truly is, as an idea, ex nihilo: violating a rudiment of dialectic, it generates a novel definition of "creare” as meaning to produce out of nothing, on the basis of nothing but this definition (15:14-16). The concept “creare,” whether in Latin, Greek, or Hebrew, entails making something out of some material; and so if Scripture has God creating, even the darkness Genesis mentions must be a something, or God according to the proper definition would be creating and also not creating: "Si tenebrae sunt nihil, Deus certe creando tenebras creavit nihil, id est, creavit et non creavit, quae contradicentia sunt” [If the darkness is nothing, God surely by creating darkness created nothing, that is, he created and did not create, which are contradictories] (15:16). If creation means a certain thing, that is, and if God did that thing understood by that meaning, then he must have done so in accordance with the thing's proper specifications. This divine conformity to logic, moreover, is strongly implied in Milton's insistence that orthodoxy gains nothing from ex nihilo in answering for the diversity, much of it seemingly ill, of an inherently good creation. The imperfection of creation remains problematic, he reasons, whether that creation springs from nothing or from God; in thus pointing out how ex nihilo was merely a ducking of the question, Milton is also pointing to his general dissatisfaction with such a move, 
that would frame the concept of creation with mere miraculousness. Body cannot come from spirit? Well, “multo minus inquam ex nihilo” [all the less, indeed, from nothing] (15: 22-24). Ex nihilo is magic, not logic_-such an indictment bespeaks how deeply Milton’s commitment to logic goes. His God is utterly free to create or not (15:30), but having created, must create, must create good, and must be good in creating — simply labeling him and his creation good is not enough. The preferred opinion is not the one geared most easily to depict the creator's omnipotence and omni-benevolence, but the one that depicts them in reconcilement with a philosophically valid cosmology and with the Bible (see Danielson 34-36).

Ex deo, in other words, is the preferred creation theory because, without abdicating logic, ex nihilo was no better equipped to explain diversity and imperfection, and otherwise, ex deo follows better from logical laws, ones as pertinent to God as they are to anyone or anything. Of these one could probably cite a great many, but to me two are salient, not only for permitting us to name Milton’s logical tools, but also for being tools he ascribed especial force to; proving his ex deo opinion, he also was attesting to its prove-ability (“videar mihi probasse” (15:26)).

The first is contrariety, in particular the argument of privatives, discussed 1.17 of Art of Logic (11:142-50). Privatives are finite contraries; whereas with contradictions negation is infinite, with privatives it is finite, insofar as one thing negates another not everywhere, but by what is proper to it: seeing and not seeing are contradictions, whereas seeing and blindness are privatives, blindness being the negation of seeing in a subject to which seeing is proper. Venturing disagreement with Aristotle, Milton calls privatives the greatest contrariety. Chapter 1.7 of Christian Doctrine closes the case against ex nihilo creation with a version of the argument of privatives: God is properly infinite, and what is infinite cannot admit any addition to itself; but whatever came into being which was not first from God and in God would be added to him (15:26). The presence of any addition negates infinity, so with infinity assumed, there can be no addition, nothing in any way apart from God. It might be said, too, that Milton’s earlier point about creation as an action is formed of privatives (15:18): no agent acts outside of itself unless there is a passive something for it to act upon; therefore God could not perform the action of creation with 
nothing there to receive that action ("necesse fuit aliquid iam tum fuisse, quod vim eius agendi potentissimam patiendo reciperet” [it was necessary that something existed, which by passivity might receive his most potent force of acting]). The lack of a passive receptor negates proper action—and creation is the most proper of actions. Therefore there must have been a receptor.

The second involves causality. ${ }^{17}$ In line with classic precedent, Art of Logic early on asserts the centrality of cause to demonstration: "erit clarior demonstratio, quo causa certior, propior, praestantior" [the clearer the demonstration, where the cause is more certain, more immediate, more prominent] (1.3, 11:30). On creation, of course, the relevant causation is material, and on material cause, Art of Logic 1.6 is unsurprising: "Quales autem res ipsae sunt, talis materia earum esse debet” [as the quality of how things are, so should their matter be] (11:52). A bit more developed, along Ramist directives, is the use of cause in distribution: "Distributio ex causis est, quando partes sunt causae totius” [Distribution out of causes is, when the parts are causes of the whole]; incidentally, we are here told that "Hîc distributio integri in sua membra praecipue laudatur” [Here distribution of the whole into its parts is especially commended] $(1.26,11: 230)$. The most accurate distribution is into dichotomy, but nevertheless the four causes could still be dichotomized, with efficient and material causes on one side and final and formal causes on the other $(1.3,11: 30 ; 1.25,11: 228-30)$. Hence in Christian Doctrine 1.7 , creation is the whole, and, if we go by orthodoxy, distributing it into its causes will lead to nothing as a material cause—which it cannot be. Nothing cannot be a cause at all; and so by ex nihilo the distribution would be impossible, with half of the causes, material and also formal as well, nullified. This is philosophically inappropriate, and ex deo is the necessary solution. Indeed, God cannot be thought to have created creation merely efficiently and finally, since none can deny “omnes causas in se contineat et complectatur” [he contains and encompasses all causes in himself] (15:20). Creation must be the effect of God, in every way, including in the constitution of its matter.

${ }^{17}$ On material cause see for example Curry 165-66; Sewell 167-73; Fisher 49-50; Connor 193-94. 
The demonstration of the non-annihilation corollary $(1.7,15: 26)$ draws upon similar arguments, beyond pointing to bare contradiction (God's making nothing “contradictionem infert” [brings in a contradiction]). ${ }^{18}$ Milton plainly declares the impossibility of annihilation, based on the foregoing: “progrediendum censeo ad id quod necessario sequitur, cum non solum a Deo, sed ex Deo sint omnia, non posse quicquam rerum creatarum in nihilum interire” [I judge it meet to proceed to that which necessarily follows, that since not only by God but out of God all things are, it is not possible for any created thing to perish into nothing]. Creation being materially God-stuff, it absolutely cannot lend itself to not-being. After noting the lack of mention of any such annihilation in Scripture, Milton first makes the point that a distribution out of causes yields an impossibility, in this case with regard to the final cause: God does all things to a proper end, and "nihil autem neque Dei, neque rei cuiuspiam finis esse potest” [nothing can be an end neither of God nor of anything]. As ex nihilo creation impossibly lacks a material cause, so does annihilation impossibly lack a final cause. No good end could possibly come of annihilation, so God is incapable of having it as a motivating cause. Milton springs from this argument to a second, related one, using privatives: “Nihil autem neque bonum est neque aliquid: Ens omne est bonum, non ens non bonum. ex ente igitur et bono non bonum facere sive nihil, nec bonitati nec sapientiae Dei consentaneum est” [Nothing is not a good, nor is it a something: all Being is good, not being not good. Therefore out of being and good to make not-good or nothing, is congruous with neither the goodness nor the wisdom of God]. The not-good of not-being is contrary to the good of being, it appears, not only by contradiction but by the superior contrariety of privation; being and goodness being present, they negate not-being and notgood. Since, as we see yet again, it's un-Godlike for God to violate logic, he cannot treat things as though they could have properties of which he made them to be deprived.

By some of the strongest reasons at his disposal, then, Milton has made the case for everything in creation coming from God. The diversity of the things in that creation, issuing from a multiform and

\footnotetext{
${ }^{18}$ For the non-contradiction principle precluding annihilation see for example Saurat 95-96; Robins 64; Adamson 773-74; Marjara 254-55; Teskey 100.
} 
inexhaustible virtue in him, one not accidental but substantial (“eamque substantialem non enim accidentalem”), only further evidenced God's omnipotence and omni-benevolence; thus the impossibility of annihilation was undeniable, for thereby God would be undoing his own substance and goodness: “neque enim materia illa res mala est, aut vilis existimanda, sed bona, omnisque boni postmodum producendi seminarium; Substantia erat, nec aliunde quam ex fonte omnis substantiae derivanda, indigesta modo et incomposita, quam Deus postea digessit et ornavit” [nor should that matter be thought an evil or vile thing, but good, the seed-plot of all subsequent good meet to be produced; it was substance, not otherwise than derived out of the font of all substance, unprocessed and un-composed, which God afterwards processed and decorated] (1.7, 15:20-22).

From this argument, the significance of "all in all” would seem cemented_- “all” must mean all. There isn't anything not God in substance, and absolutely no thing, consequently, can be reduced to nothing. And yet what must the next step be? Validity demands universal salvation. But Milton, as we have seen, cannot follow the logic through—-the devils, after all, are reserved for punishment. With goodness and God-ness underpinning everything, and with nothing created being capable of dissolving to non-existence, would not we infer that same eventual conversion back to good, and back to God, inferred by Gregory and Origen? God cannot undo himself—but how was interminable evil and misery, sustained forever in beings made of God's own substance, not such a self-undoing? Universal salvation is the rational conclusion, but it cannot be purchased. The missing consequent, we can sense universal salvation only vaguely, as a haunting ought-to-be.

As Milton would have seen had he been able to read the philosophy of his hero John Wycliffe, ${ }^{19}$ one way to resolve this problem was sheer determinism. In a fragment On Annihilation, Wycliffe

\footnotetext{
${ }^{19}$ For admiring remarks on Wycliffe see Doctrine and Discipline of Divorce (CPW 2:231-32); Areopagitica (CPW 2:552-53). For frustration at the dearth of Wycliffe's writings, see Tetrachordon (CPW 2:707-08). For Wycliffe's case against annihilation considered next to Milton's mortalism, see Sugimura 145-46.
} 
systematically proved the prospect impossible, in part because it would mean God's destruction of himself—properly to annihilate his creations he would have to destroy the idea of them, which adhered in himself (290-91). And just as God, pure being, cannot visit non-being upon himself, neither can he be merciless or purposeless; no creaturely sin can deserve annihilation as punishment (299-300), and no part of creation isn't supposed to be there (294-95), all of it progressing toward the fulfillment of its perfection (306-07). In the De Ente Wycliffe makes the remarkable stipulation that this perfection very much encompasses eternal hell: "large melius est illis [creaturas racionales quas scivit perpetuo dampnandas] esse sic dampnatas quam non esse. Ideo facit illis magnam graciam et multiplicem” [by a great deal it is better for them [rational creatures whom God knows are going to be damned eternally] that they be thus damned than not exist. Indeed, he does them great and manifold grace]; “Ideo non est credendum quod deus umquam proposuit salvare totam speciem, set eternaliter proposuit dampnare singulos prescitos ad decorem universi [Indeed, it's not to be believed that God ever proposed to save the whole race, but eternally he proposed to damn foreknown individuals, toward the beauty of the universe] (230-31). But for Milton, the beauty of hell was not apparent; and for him, we remember, it were well, from their standpoint, for the damned to be annihilated (“Quod si fieret, praeclare sane cum damnatis actum esset”). Indeed, in Paradise Lost hell's contribution to creation's beauty is mentioned only offhand, in unexplored paradox: “A universe of death, which God by curse / Created evil, for evil only good” (2.622-23).

The paradox acknowledges the weirdness of God's having created hell, but contains that weirdness within itself, in a circular jumble of evil and good; the idea is couched as a paradox not amenable to parceling out, which works not only to discourage such parceling, but also to insinuate a dissociation between the creator and this aspect of his creating. The insoluble paradox, that is, functions as a device to grant the poem something of what ex nihilo granted orthodoxy: a buffer zone insulating God from the ugliness of an eternal hell. More elaborate insulation is provided by Chaos and Moloch. 
The problem of the negative quality of Chaos in Paradise Lost has often been remarked on, with the focus of assays of it typically turning to Book Seven. There, Chaos is equated with the prime matter mentioned in Christian Doctrine ("Substantia . . indigesta modo et incomposita”), and a statement on God's relationship with the "vast immeasurable abyss” (211), “chaos and the world unborn” (220), is issued by the Father himself: "Boundless the deep, because I am who fill / Infinitude, nor vacuous the space. / Though I uncircumscribed myself retire, / And put not forth my goodness, which is free / To act or not, necessity and chance / Approach not me, and what I will is fate” (168-73). Learned and insightful though they are, glosses on God here that would elucidate the nature of his continuity with Chaos do not, in my estimation, quite do so. God might seem to refer to the "retraction" of his goodness, ${ }^{20}$ or to be identifying the prime matter as mere potential, with goodness categorically irrelevant ${ }^{21}$; but in either sense how God infuses the primordial phase of his creation with goodness becomes obscured, leading a number of other commentators to distinguish Chaos and prime matter, ${ }^{22}$ or to suggest that Chaos itself figures the obscurity. ${ }^{23}$ As an important proponent of the latter view I would count Regina Schwartz, whose dissection of the conundrum posed by a hostile Chaos has stood the test of time: "the inference of an evil chaos [is] so difficult to escape that it is not worth trying” (340). As Schwartz points out (340-48), the boundlessness of Chaos even here in Book Seven seems, by the poem's standards, which identify good with order and containment, to mark it pejoratively. God's words assert his involvement with all that exists, both in filling it and in controlling it ("what I will is fate”), and yet also detach him, implying that good only comes with the imposition of form. For Schwartz, this inimical shade to Chaos is Milton’s conveying of contradictions at the heart of Christianity itself, that God creates what is good yet has evil germinating in it from some time in some way—and that God has no enemy yet we need redemption from one (363-67). But since, as Schwartz effectively describes (348-49), we have been vividly introduced to

\footnotetext{
${ }^{20}$ Famously suggested by Saurat 102-08; Robins 44-59, 85-94. This interpretation, which Fowler seems to endorse (see his note), is so prominent that it deserves mention, though since ably refuted, for example by Sewell 124-34; Patrides 33.

${ }^{21}$ Curry 48-91, esp 72-73; Marjara 89-102; Danielson 37-49; Rumrich “Matter of Chaos” 1040-41, “Things” 40-41.

${ }^{22}$ Fallon 190-92; Donnelly 90-94.

${ }^{23}$ Schwartz 362-64; Teskey 65-106, esp 84-85, 94-99; Sugimura 231-79, esp 233-34; Mascetti.
} 
Chaos as an enemy in Book Two, where it not only recognizes but also befriends Satan, I sense that the contradiction Milton is most intently grappling with is much more peculiar to himself. Book Seven while it does nothing to cancel an ex deo creation also refrains from overturning the baleful Chaos of Book Two. There, Chaos is baleful, even though as in Book Seven it is also designated as prime matter, "His dark materials to create more worlds” (2.916). To express the array of creation-problems basic to Christianity would hardly call for a baleful Chaos. They are challenging enough.

The creation-problem being faced, and finessed, is indeed not basic, but Miltonic: a good or even a neutral Chaos threatens to alert us to the universal salvation that is the logical consequent of ex deo and the non-annihilation corollary. A Chaos evincing a derivation from and kinship with the creator and an intrinsic goodness imparted from him would direct us not only back toward its provenance from him but also ahead toward its logical reintegration with him; and such a notion, devastating in any case where an eternal hell is necessary, were especially so in Book Two where the fact of hell is so fresh in our minds, its first citizen Chaos's interlocutor even now. So, instead of this devastating logical direction--the invariable path to our befuddlement at how divine benignity could fail to reconvert and reincorporate its fallen elements, which remain its very self, back into itself--we get misdirection. We get a philosophically fuzzy though strangely persuasive idea of partitioning and self-determined alienation; without any assertion of some undue freedom from God's jurisdiction, we meet a Chaos that, much like the Satan and the devils we have met, seems apart from God and from good, such that we are disinclined to imagine any re-union, and feel its unseemliness if we begin any such imagining. A hostile Chaos is necessary to instill a feeling of comfort in us with a multiverse of compartments some of which will never return to an original monad. Happy to help, for it gains from "Havoc and spoil and ruin” (2.1009), Chaos tells Satan where to go- - and hereby steers us away from going where we mustn’t go.

From the view of this Chaos, for God to impose form and create worlds is to be "Encroached on" (2.1001); though its true unity with them is hinted at by the sense of their making as an allotment from a whole, Chaos speaks as though the constitution of these worlds were somehow not itself, as though their 
making merely claimed its territory, crossed its “frontiers" (2.998), not used its own being as raw material. It speaks as though divorced (pardon the allusion) from the worlds' origin and from their destiny; Chaos with its antagonism dissociates itself from created space and time. Hurling the new created world into havoc and ruin would, it seems, be to recoup some of these territorial losses: hereby a Christian faith is invoked that havoc and ruin will not totally subsume our world, and if so, it might be easy to overlook the incongruity of any sector of creation falling into permanent ruin—of ex deo and nonannihilable realms absolutely stable in their instability.

This effect in part works, I submit, by means of the temporary prying apart by Chaos here of the foundational logical structures. The distribution into causes, for example, which proves God as much the material cause as the final, is implicitly dismantled by Chaos’s territorialism and intention to "gain” longterm from spoil and ruin: indignant at being spatially infringed upon by God's creation, Chaos seems to present itself as materially distinct from both him and it, and perhaps as not properly matter at all; and more, foreseeing a possible chaos that could metastasize by dint of Satan's planned attack, Chaos seems to present itself as somehow outside of God's planned all in all. It seems to Chaos, that is, that the primordial stuff of creation is somehow not ordained toward creation's final cause, and indeed that any sort of “final cause” pertains not to itself. Whereas Satan resists God’s will, Chaos implies itself functioning irrespective of that will or indeed any willing toward an end. And just as the force of material and final cause distribution is temporarily suspended here, so too is the force of the contrariety of privatives. Chaos, along with its consort "sable-vested Night, eldest of things" (2.962), is fashioned thoroughly to muddle any and every reasoning-by-negation. Night is both a neither/nor and a both/and, at once a thing — the first thing--and a non-thing, and nothing (“original darkness” (2.984)), and just so, Chaos is a confusion of being and not-being, and of good, not-good, and evil. This confusion tends to badness, as we have seen, but it is a badness of imprecision. Whereas prime matter must be good and must come from God, to the negation of nothing both before and after creation, Chaos approves of chaos in the universe and we can say little more of it. Were it confirmed as good God-matter, and were it to 
oppose Satan, Chaos would lose much of this ambiguity-ambiguity which helps make it feel fruitless for us to ponder why it is, in a universe so constituted, that Satan will one day need to be shut inside the prison he has just escaped from, and forever at that, with no escape possible.

The alogical chaos of Chaos staves off this pondering, and soon, with Book Three's flight up to heaven and God's speaking for himself, in the familiar arguments of Arminianism, we regain the ballast of logical frames of reference ${ }^{24}$; but Chaos has not been Book Two's only misdirection play. Moloch also waves us off from the logical path to universal salvation, but here instead of by what is alogical, the threat is deflected by what seems to be anti-logical, a line of furiously invalid reasoning apt to be marginalized and drowned out. Moloch’s “sentence ... for open war” (2.51) is not often assessed on its logical merits, ${ }^{25}$ and indeed Belial's and Mammon's speeches in the infernal debate do not dispose us to look back and heed Moloch much, if at all. Truly, Mammon’s discourse by proposing an embrace of hell, inviting the devils to wonder “what can heaven show more?” (2.273), thoroughly demolishes any traces of respect for Moloch’s plan, being its diametric opposite—and Mammon’s “sentence pleased” (2.291). In advocating an attitude of happiness with hell, Mammon has both embroidered on Satan's concept of the mind as its own place (1.254), and built on Belial's longwinded point that many prospective punishments could be far worse than what they now endure. Thus Mammon consolidates a line of thought that makes hell comparatively mild and self-chosen, in the sense of deliberately being preferred to possible alternatives; and along the way, Belial has rated annihilation as much severer—_To be no more; sad cure” (2.146)—and as probably in theory and definitely in practice impossible: "who knows, / Let this [annihilation] be good, whether our angry foe / Can give it, or will ever? How he can / Is doubtful; that he never will is sure” (2.151-54). Milton, therefore, has deftly slipped us away from Moloch’s argument,

\footnotetext{
${ }^{24}$ That is, we can again evaluate the poem's content in logical terms; whether the logic holds is beside my point here.

${ }^{25}$ I cannot find that it has been much focused on at all; for an assessment of it as Satan-like false reasoning, see Harinder S. Marjara, “Angelic Motion and Moloch's False Rhetoric,” Milton Quarterly 19 (1985): 82-87.
} 
with Belial painting it merely fatuous--the pro-war argument makes Belial “laugh” (2.204)--and has simultaneously moved the devils toward a mindset (acceptance of hell) and toward a scheme (sneakattacking us) suited to their role in demonstrating the great argument for the providence of God and the free will of his creatures. But Belial has only side-stepped Moloch, not invalidated his logic; he has merely reversed the value Moloch had given to annihilation relative to their current hell pains, and not proven anything. Moving from Belial to Mammon, we get the sensation of Moloch having been refuted in the process, when he has actually not been. Such a sensation is facilitated by our introduction to Belial as a consummate rhetorician, whose "tongue / Dropped manna, and could make the worse appear / The better reason” (2.112-14). Primed to take Belial as a subtle seducer, who will lure innumerable innocents into sin, we can easily miss in what vein he is "false and hollow" even here (2.112): for all that is good in the universe his reason is the better reason; but it is hollow as reasoning.

In fact, Moloch’s reasoning is impeccable, and our presupposition of Belial’s rhetorical superiority lulls us into neglecting this. To wit, if the goal is to subvert God, Moloch's argument on behalf of never-ending war is the winner, in that his logic precludes goodness and exposes a self-contradictory creator. Unlike with the other devils, who have diluted priorities, such subversion is assumed by Moloch to undergird everything else- - to be the only term upon which any argument can be predicated. Moloch closes his case by affirming opposition to God to be not only the central but the sole principle: they must conceive of their power as "sufficient to disturb his heaven, / And with perpetual inroads to alarm, / Though inaccessible, his fatal throne: / Which if not victory is yet revenge” (2.102-05). Perpetual alarm and disturbance in God's order is what they are able to accomplish—and Moloch says that such is all that is needed to achieve revenge, which is what they should strive for. For Moloch, in other words, their sole directive is to express their hate for God, and this is effectively done if done perpetually. This proposition, that opposition to God is all there is for them, and that God can be effectively opposed through complete and sustained intransigence, turns an intolerance for hell and a preference for annihilation into much more than a mere subjective value-judgment, as Belial would have it; the consequents are no less than a 
universe devoid of good, a virulently hellish hell, and a God both tyrannically destructive and selfdestructive.

If we yet once more apply distribution into causes and privatives, these consequents are thrown into relief. On the one hand, from Moloch's position on hell and annihilation we must infer a God that is the cause, on every level of causality, of all that by definition he must not cause. Moloch holds that "More destroyed than thus / We should be quite abolished and expire" (2.92-93), and so were God to "reduce / To nothing this essential, happier far / Than miserable to have eternal being” (2.96-98). If being depends on subverting God and opposing God’s good, then annihilation must indeed surely be more selfactualizing, and less to be destroyed, than passively sitting "vassals of his anger” in hell (2.90); and as we know, and Moloch suspects, the mercy of annihilation is denied them: "if our substance be indeed divine, / And cannot cease to be, we are at worst / On this side nothing” (2.99-101). If God cannot make them nothing, and lend them that kindness, he has still reduced them to nothing, and so incongruously made nothing, in another way, by confining them in an intolerable eternal hell. Moreover, this causing of nothing on God's part is by Moloch's unrelenting resolve exacerbated ad infinitum, as he foresees “Turning our tortures into horrid arms / Against the torturer” (2.63-64) and confronting God with "His own invented torments” (2.70). If he does not annihilate them, God will be constrained by unending war to become even more of a torturer who invents tortures, to be, and be again and again, the efficient and final cause of a painful hell—and too, as we will learn from Raphael, logically he is the material cause of it as well. As its mover, its maker, and its matter, God, as Moloch’s endless attack would prove, is hell. And hence we see where, on the other hand, the privatives come in. In the service of opposing God, Moloch would gain the revenge of unmaking God and heaven, of forcing them to have and to be everything of which they are supposed to be absolutely deprived: "when to meet the noise / Of his almighty engine he shall hear / Infernal thunder, and for lightning see / Black fire and horror shot with equal rage / Among his angels; and his throne itself / Mixed with Tartarean sulphur, and strange fire” (2.64-69). Moloch remembers from experience that, as Michael himself declared, "Heaven the seat of 
bliss / Brooks not the works of violence and war” (6.273-74); luckily for God's order, the rest of the devils, with Belial's help, forget it. If the devils attack earth, good, according to the poem's great argument, can still come of it; but no good can possibly come of the cataclysm envisaged by Moloch. Either that "essential” which God created would be reduced to uncreation, or, absent annihilation, God would either have to allow heaven to admit hell, or have to make the evil of hell more evil, its torments more tormenting, unto eternity. The last prospect must be the likeliest—but is no less an undoing of everything that is God than the first two.

This sense of undoing is all the more incisive if we reference Milton's ex deo creation, which Moloch's discourse, tilting as it does toward the impossibility of annihilation, might well encourage us to do--“if our substance be indeed divine” has an ex deo ring to it; and perhaps this effect is best appreciated if we consider the way in which by an endless war on heaven the distinction between God and Moloch would collapse: Moloch’s plan would make God the eater of his own children. As Milton would have known, Moloch, whom he has described as a "grim idol” receiving sacrificed children in a burning oven (1.392-96), was thought a version of Saturn, the classical titan who swallowed his offspring. As Thomas Heywood's tome on angelology explained, Moloch was equated with Saturn, "whom the Poets feigne to haue eaten and deuoured his owne children” (389-90). ${ }^{26}$ This symbolism of consuming one’s own children captures what Moloch would do to God through unrelenting violence: conflate God with Moloch/Saturn, as he would have to destroy his own divine substance, incinerate that which sprang from his own being. Inducing God to annihilate the devils were an obvious way to this, but inducing him to intensify endlessly the constrictions and the torments of hell is another; the devils being constituted of God-stuff, for God to be perpetually crushing them is tantamount to reducing to nothing his own essential. This would truly mean, to repeat Origen, that God "hates, and threatens, and destroys his own offspring.”

\footnotetext{
${ }^{26}$ See also Robert Burton, The Anatomy of Melancholy, ed. Holbrook Jackson (New York: Vintage, 1977) 1.2.1.2, 197; Alexander Ross, Pansebeia, or, A View of All Religions in the World (London, 1655) 67. See also "Moloch" in A Milton Encyclopedia, ed. William B. Hunter (Lewisburg: Bucknell UP, 1979) 5:150.
} 
Logically, God cannot annihilate an ex deo creation; but as Moloch’s logic underscores, than in an eternally tormenting hell, they, in substance divine, cannot be more destroyed.

Because Belial and the other devils put Moloch to silence, God's order is never disturbed and alarmed in any such way; so that God will never need to suppress an endless violent insurrection, Milton suppresses Moloch’s logical one. But he does so by sleight of hand. If we examine him, Moloch has allowed us to probe a bit into the logical dilemma presented by the coexistence of an eternal hell and an ex deo, non-annihilable creation. And further, such an examination nudges us toward desiring a solution to this dilemma, for Moloch images, terrifyingly, the very inversion of a God justified to men. How do we conceptually maintain the polar opposition between God and Moloch, the creator of versus the eater of children? The solution is universal salvation: the eventual annihilation of evil and hell and the reintegration of everything - every thing that partakes of being--back to God, all in all. But Moloch, like Chaos, is calibrated to make us miss this consequent, much as it is not allowed to emerge in the creation and conflagration chapters of Christian Doctrine. It must be missing because for Milton, unlike for Gregory and Origen, the Bible finally cannot permit it; in the Moloch and Chaos passages there lies dormant a conclusion, concerning creation's ultimate fate, that logically results from Milton's collection of premises but that he is not theologically able to conclude. In closing, however, I want to reemphasize that this dormancy speaks more to the affirmative view of Milton’s logicality than to the negative. He could not add universal salvation to the architecture of the great argument; but by his covering over and gliding past this gap, he indicates the significance to him that the architecture as a whole remain valid and sound.

\author{
Works Cited
}

Adamson, J. H. “Milton and the Creation.” Journal of English and Germanic Philology 61 (1962): 756- 
78.

Ames, William. The Marrow of Sacred Divinity Drawne ovt of the Holy Scriptures (London, 1643).

Arnold, Richard. Logic of the Fall: Right Reason and [Im]pure Reason in Milton's Paradise Lost. New York: Peter Lang, 2006.

Brodwin, Leonora Leet. “The Dissolution of Satan in Paradise Lost: A Study of Milton’s Heretical Eschatology.” Milton Studies 8 (1975): 165-207.

Burden, Dennis. The Logical Epic: A Study of the Argument of Paradise Lost. Cambridge, MA: Harvard UP, 1967.

Connor, John T. “Milton’s Art of Logic and the Force of Conviction.” Milton Studies 45 (2006): 187-209.

Cummins, Juliet. “Matter and Apocalyptic Transformations.” Milton and the Ends of Time. Ed. Juliet Cummins. Cambridge: Cambridge UP, 2003.169-83.

Curry, Walter Clyde. Milton’s Ontology, Cosmology, and Physics. Lexington: U of Kentucky P, 1966 (1 $1^{\text {st }}$ pr 1957).

Danielson, Dennis. Paradise Lost and the Cosmological Revolution. Cambridge: Cambridge UP, 2014. Donnelly, Phillip J. Milton’s Scriptural Reasoning: Narrative and Protestant Toleration. Cambridge: Cambridge UP, 2009.

Fallon, Stephen M. Milton Among the Philosophers: Poetry and Materialism in Seventeenth-Century England. Ithaca: Cornell UP, 1991.

Fish, Stanley. How Milton Works. Cambridge, MA: Belknap P of Harvard UP, 2001.

Fisher, Peter F. “Milton’s Logic.” Journal of the History of Ideas 23 (1962): 37-60. 
The Geneva Bible: The Annotated New Testament 1602 Edition. Ed. Gerald T. Sheppard. Cleveland:

Pilgrim P, 1989.

Gregory of Nyssa. Select Writings and Letters. Trans. William Moore and Henry Austin Wilson. The Nicene and Post Nicene Fathers $2^{\text {nd }}$ Series Vol. 5. (Grand Rapids: William B. Eerdmans, 1890.

Hart, D. Bentley. “Matter, Monism, and Nature: An Essay on the Metaphysics of Paradise Lost.” Milton Quarterly 30 (1996): 16-27.

Haskin, Dayton. Milton’s Burden of Interpretation. Philadelphia: U of Pennsylvania P, 1994.

Herman, Peter. Destabilizing Milton: "Paradise Lost” and the Poetics of Incertitude. Basingstoke: Palgrave Macmillan, 2005.

Heywood, Thomas. The Hiearchie of the Blessed Angells. London, 1635.

Howard, Leon. “'The Invention’ of Milton’s ‘Great Argument’: A Study of the Logic of ‘God’s Ways to Men.'” Huntington Library Quarterly 9 (1946): 149-73.

Hunter, William B. “Milton’s Materialistic Life Principle.” Journal of English and Germanic Philology 45 (1946): 68-76.

Jacobus, Lee A. Sudden Apprehension: Aspects of Knowledge in Paradise Lost. The Hague: Mouton, 1976.

Kelley, Maurice. This Great Argument: A Study of Milton's De Doctrina Christiana as a Gloss upon Paradise Lost. Princeton: Princeton UP, 1941.

Lieb, Michael. Theological Milton: Deity, Discourse, and Heresy in the Miltonic Canon (Pittsburgh: Duquesne UP, 2006. 
Marjara, Harinder Singh. Contemplation of Created Things: Science in Paradise Lost. U of Toronto P, 1992.

McColley, Diane Kelsey. “'All in All’: The Individuality of Creatures in Paradise Lost.” 'All in All’: Unity, Diversity, and the Miltonic Perspective. Ed. Charles W. Durham and Kristin A. Pruitt. Selinsgrove: Susquehanna UP, 1999. 21-38.

Mascetti, Yaakov. “Satan and the ‘Incompos’d’ Visage of Chaos: Milton’s Hermeneutic Indeterminacy.” Milton Studies 50 (2009): 35-63.

Milton, John. Complete Prose Works of John Milton. Ed. Don M. Wolfe et al. 8 vols. New Haven: Yale UP, 1953-1982.

---. Paradise Lost. Ed. Alastair Fowler. 2nd ed. Harlow: Longman, 1997.

---. The Works of John Milton. 18 vols. New York: Columbia UP, 1931-1938.

More, Henry. The Immortality of the Soul. A Collection of Several Philosophical Writings of Mr. Henry More. $2^{\text {nd }}$ ed. London, 1662. Separate pagination.

---. A Platonick Song of the Soul. Ed. Alexander Jacob. Lewisburg: Bucknell UP, 1998.

Myers, Robert M. “'God Shall Be All in All’: The Erasure of Hell in Paradise Lost,” Seventeenth Century 5 (1990): 43-53.

Origen. Origen. Trans. Frederick Crombie. The Ante-Nicene Fathers Vol. 4. Buffalo: The Christian Literature Publishing Co, 1887.

Patrides, C. A. Milton and the Christian Tradition. Oxford: Clarendon, 1966.

Raymond, Joad. Milton’s Angels: The Early Modern Imagination. Oxford: Oxford UP, 2010. 
Reisner, Noam. Milton and the Ineffable. Oxford: Oxford UP, 2009.

Robins, Harry F. If This be Heresy: A Study of Milton and Origen. Urbana: U of Illinois P, 1963.

Rumrich, John. “Milton’s God and the Matter of Chaos.” PMLA 110 (1995): 1035-46.

---. “Things of Darkness: Sin, Death, Chaos.” The Cambridge Companion to Paradise Lost. Ed. Louis Schwartz. Cambridge: Cambridge UP, 2014. 29-41.

Saurat, Denis. Milton: Man and Thinker. London: J. M. Dent \& Sons, 1944.

Schwartz, Regina. “Milton’s Hostile Chaos: ‘ . . And the Sea Was No More.”’ ELH 52 (1985): 337-74.

Sewell, Arthur. A Study of Milton’s Christian Doctrine. London: Oxford UP, 1939.

Shawcross, John T. “Confusion: The Apocalypse, The Millennium.” Milton and the Ends of Time. Ed. Juliet Cummins. Cambridge: Cambridge UP, 2003. 106-19.

---. “Stasis, and John Milton and the Myths of Time.” Cithara 18 (1978): 3-17.

Sugimura, N. K. 'Matter of Glorious Trial': Spiritual and Material Substance in Paradise Lost. New Haven: Yale UP, 2009.

Teskey, Gordon. Delirious Milton: The Fate of the Poet in Modernity. Cambridge, MA: Harvard UP, 2006.

Trevor, Douglas. “Milton and Oneness.” Milton Studies 49 (2008): 77-107.

Wollebius, Johannes. Compendium Theologiae Christianae. Cambridge, 1648.

Wycliffe, John. De Ente Librorum Duo. Ed. Michael Henry Dziewicki. Wyclif's Latin Works Vol. 4. New York: Johnson Reprint Co., 1966). 